\title{
PEMANFAATAN KOMPOS DARI LIMBAH BAGLOG JAMUR TIRAM (Pleurotusostreatus) SEBAGAI MEDIA TUMBUH TANAMAN SAWI HIJAU (Brassica rapa var.parachinensis $\mathbf{L}$. .)
}

\author{
Rosmauli $^{1}$, N. Gofar ${ }^{2}$, L.Hanum ${ }^{3}$ \\ ${ }^{1}$ Biologi Lingkungan Program Studi Pengelolaan Lingkungan Universitas Sriwijaya \\ ${ }^{2}$ Jurusan Tanah Fakultas Pertanian Universitas Sriwijaya \\ ${ }^{3}$ Jurusan Biologi Fakultas MIPA Universitas Sriwijaya \\ Email: rosmaulizainal@gmail.com
}

\begin{abstract}
ABSTRAK
Peluang budidaya jamur tiram putih (Pleurotusostreatus) cukup diminati oleh masyarakat karena usaha ini memiliki kelebihan diantaranya adalah modal murah, cepat perkembangbiakan dan cukup menguntungkan., tetapi limbah baglog yang dihasilkan belum maksimal dimanfaatkan. Pemanfaatan limbah dapat dijadikan kompos, dengan menggunakan aktivator alami dan dosis tertentu.Penelitian dilakukan di SMAN 1 Palembang dari bulan Januari sampai Mei 2015. Kriteria kompos yang baik adalah dengan aktivator pukan sapi $10 \%$ dengan waktu pengomposan selama satu bulan, komposisi kompos yang dihasilkan: C-Organik 28,96, N-Total 1,30, pH 7,91, C/N 22, dan KTK 75. Komposisi media tumbuh tanaman sawi hijau (Brassica rapa var. parachinensis L.) yang baik adalah K3 (60 tanah : 40 kompos) v/v, Tanah tersebut tergolong tanah masam dengan pH 4,56.Kandungan Corganik tergolong rendah $\left(1,01 \mathrm{gkg}^{-1}\right)$. Kandungan Nitrogen tanah tergolong rendah yaitu sebesar $0,10 \mathrm{gkg}^{-1}$. Kandungan $P$ tersedia tanah tergolong sedang dengan kandungan sebesar $10,35 \mathrm{mgkg}^{-1}$. Kandungan basa tanah berupa $K$ sebesar 0,51 $\mathrm{cmol}_{c} \mathrm{~kg}^{-1}$ (tinggi); Na sebesar 0,11 $\mathrm{cmol}_{c} \mathrm{~kg}^{-1}$ (rendah); Ca sebesar 1,18 $\mathrm{cmol}_{c} \mathrm{~kg}^{-1}$ (sangat rendah), dan $\mathrm{Mg}$ sebesar 0,45 $\mathrm{cmol}_{c} \mathrm{~kg}^{-1}$ (rendah). Rasio C/N tanah tergolong tinggi yaitu sebesar 10. Kapasitas Tukar Kation (KTK) tanah tergolong rendah sebesar 15,23 $\mathrm{cmol}_{\mathrm{c}} \mathrm{kg}^{-1}$, kejenuhan Al tergolong rendah yaitu sebesar 13,7 \%, serta kejenuhan basa yang tergolong sangat rendah yaitu sebesar 14,77\%. dapat dilihat dari jumlah daun mulai bertambah pada minggu ke empat berjumlah 4 lembar, luas daun 252,5 $\mathrm{cm}^{2}$, biomassa basah 42,22 gram, dan biomassa kering 2,46 gram. Jumlah klorofil 51,4 (daun atas/muda) dan 36,8 (daun bawah/tua)
\end{abstract}

Katakunci: aktivator, baglog, budidaya, klorofil ,limbah, pukan.

\begin{abstract}
Opportunitywhite oystermushroom cultivation(Pleurotus ostreatus) quite interested bythe businesscommunity becauseithas advantagesincludelowcapital, rapidproliferationandquiteprofitable., Butthe wastegeneratedbaglognot maximizedutilized. Utilization of wastecanbe composted, using naturalactivatorand acertaindose. The study was conductedatSMAN1PalembangfromJanuary to May2015.The criteriaof good compostactivatoriswithpiles ofcow10\% withcomposting timefor a month, the composition ofthe compost produced: C-Organic 28.96, N-Total 1.30, pH7.91, C/N22, and75.CECcomposition ofthe plantgrowing mediumgreen cabbage(Brassica rapavar. parachinensisL.) that is bothK3(60 soil: compost40) $\mathrm{v} / \mathrm{v}$.The land is classified as acid soil with a $\mathrm{pH}$ 4,56.Kandungan organic $C$ was low $\left(1,01 \mathrm{~kg}^{-1}\right)$. The nitrogen content of the soil relatively low at 0.10 $\mathrm{kg}^{-1}$. The content of phosphorus content of soil classified as moderately at 10,35 $\mathrm{mgkg}^{-1}$. The content of the soil in the form of bases $K$ for 0,51 $\mathrm{cmol}_{\mathrm{c}} \mathrm{kg}^{-1}$ (high); Na for 0,11 $\mathrm{cmol}_{\mathrm{c}} \mathrm{kg}^{-1}$ (low); Ca for 1,18 $\mathrm{cmol}_{\mathrm{c}} \mathrm{kg}^{-1}$ (very low), and $\mathrm{Mg}$ for 0,45me / $100 \mathrm{~g}$ (low). C / N ratio of ground is high that is equal to 10. The cation exchange capacity (CEC) of the soil is low for 15,23 $\mathrm{cmol}_{\mathrm{c}} \mathrm{kg}^{-1}$, Al saturation relatively low at $13.7 \%$, and base saturation were classified as very low, amounting to $14.77 \%$ can be seen from the number of leaves begin to grow in the fourth week amounted to 4 sheets, leaf area $252.5 \mathrm{~cm} 2$, wet biomass 42.22 grams, and 2.46 grams of dry biomass. Total chlorophyll 51.4 (leaves on / young) and 36.8 (the lower leaf / old)
\end{abstract}

Keywords: activators, baglog, cultivation, chlorophyll, sewage, manure 



\section{PENDAHULUAN}

Budidaya jamur tiram putih (Pleurotusostreatus) di Sumatera Selatan khususnya di kota Palembang sudah mulai diminati oleh masyarakat, dikarenakan peluang usaha ini dapat dilakukan oleh setiap lapisan masyarakat terutama bagi ibu rumah tangga untuk menambah pendapatan keuangannya. Usaha ini memiliki kelebihan diantaranya adalah modal murah, cepat perkembangbiakan dan cukup menguntungkan. Salah satu pengusaha budidaya jamur dengan kapasitas baglog \pm 4.000 baglog dalam waktu 3 - 4 bulan pasca panen dapat menghasilkan limbah baglog sekitar \pm 1 ton, limbah-limbah tersebut dimanfaatkan oleh petani untuk dijadikan pupuk tanaman sayuran dengan cara menaburkan langsung ke lahan pertanian, tanpa melihat kualitas limbah sebagai pupuk.

Menurut Meinanda (2013) baglog jamur sudah banyak dimanfaatkan sebagai usaha tambahan, seperti dapat dijadikan sebagai media ternak belut, media ternak cacing dan bahan baku pupuk organik dijadikan kompos dengan menggunakan bioaktif.

Menurut hasil penelitian Mushroom Institute (2003) limbah media tanam memiliki kandungan hara seperti $\mathrm{N} 0,7 \%$, P 0,3\%, dan $\mathrm{K} 0,3 \%$ yang diperkaya dengan unsur mikro lainnya. Kandungan unsur hara ini berperan sebagai soil conditioner apabila diaplikasikan ke dalam tanah

Pengomposan bioaktif merupakan suatu proses biologi dengan penggunaan mikroba yang mampu merombak bahan selulosa, antara lain Trichoderma sp, Psudomonas, dan Streptomyces. Aktivator lain dapat juga digunakan biomassa mikroba yang berasal dari kotoran ternak sapi, karena didalamnya mengandung mikroba pendegredasi bahan organik kompleks (Suwahyono, 2014)

Menurut Supriati dan Herliana (2014), kompos adalah bahan organik berupa kotoran hewan dan bagian tumbuhan yang telah mengalami proses pembusukan. dan pelapukan. Pemberian kompos sebagai upaya untuk memperbaiki sifat -sifat tanah, karena pupuk kandang mengandung kadar C-organik, N, P, K, dan mempunyai nilai kapasitas tukar kation (KTK) yang tinggi sehingga produksi tanaman meningkat.

\section{METODE PENELITIAN}

Penelitian dilaksanakan pada bulan Januari sampai bulan Mei 2015.Tempat pengambilan dan penelitian limbah baglog di SMAN 1 Palembang Laboratorium Tanah Fakultas Pertanian UNSRI Indralaya. Alatalat yang digunakan pada penelitian ini meliputi adalah cangkul, sekop, bak fermentor, perlak, pralon berlubang, termometer, mortar, saringan, polybag, timbangan, hand sprayer,masker,sarung tangan, mistar/penggaris, oven, kertas milimeter, khlorophyll meter.

Bahan-bahan yang diperlukan adalah limbah baglog, pupuk kandang sapi, pupuk kandang ayam, benih sawi hijau merek tosakan, dan tanah.

\section{Percobaan I. Uji kematangan kompos dengan berbagai aktivator}

Perlakuan terhadap limbah baglog dan pukan masing-masing $100 \mathrm{~kg}$, pada saat pengomposan meliputi:

Kontrol = tanpa penambahan aktivator

PKA1 = pupuk kandang ayam $10 \%$

PKA2 = pupuk kandang ayam $20 \%$

PKS1 = pupuk kandang sapi $10 \%$

PKS2 = pupuk kandang sapi $20 \%$

\section{Percobaan II. Dosis kompos pada media tumbuh (tanah) tanaman sawi Hijau}

Kompos yang digunakan adalah hasil terbaik dari percobaan tahap 1, berdasarkan uji analisis laboratorium.

Perlakuan media tanam yang digunakan adalah kompos dan tanah yang dimasukkan dalam polybag dengan berat lebih kurang 2 $\mathrm{kg}$, dengan berbagai komposisi :

$$
\begin{array}{ll}
\mathrm{K} 1: 100 \operatorname{tanah}+0 \text { kompos }(\mathrm{v} / \mathrm{v}) \\
\mathrm{K} 2: 80 & \tan a \mathrm{~h}+20 \operatorname{kompos}(\mathrm{v} / \mathrm{v}) \\
\mathrm{K} 3: 60 & \tan a \mathrm{~h}+40 \text { kompos }(\mathrm{v} / \mathrm{v}) \\
\mathrm{K} 4: 40 & \operatorname{tanah}+60 \text { kompos }(\mathrm{v} / \mathrm{v})
\end{array}
$$

$\mathrm{K} 5: 20$ tanah +80 kompos $(\mathrm{v} / \mathrm{v})$ 
Tiap perlakuan diulang 3 kali dan tiap ulangan terdiri dari 3 polybag.

\section{HASIL DAN PEMBAHASAN}

Tabel 1.Komposisi hara limbah media tumbuh jamur tiram.

\begin{tabular}{|c|c|c|}
\hline Parameter & Satuan & Hasil \\
\hline C- Organik & $\mathrm{gkg}^{-1}$ & 40,13 \\
\hline N- Total & $\mathrm{gkg}^{-1}$ & 0,840 \\
\hline P- Total & $\mathrm{mgkg}^{-1}$ & 0,630 \\
\hline K- Total & $\mathrm{cmol}_{\mathrm{c}} \mathrm{kg}^{-1}$ & 0,150 \\
\hline C/N & $\%$ & 48 \\
\hline C/P & $\%$ & 64 \\
\hline
\end{tabular}

Sumber: Lab Kimia, Biologi dan Kesuburan Tanah Unsri, 2015

Tabel 2. Pengaruh Penambahan aktivator pukan terhadap C-Organik (\%), N-Total (\%), pH,Rasio C/N, dan KTK

\begin{tabular}{|c|c|c|c|c|c|c|}
\hline Minggu & Perlakuan & $\begin{array}{c}\text { C- } \\
\text { Organik }\end{array}$ & $\begin{array}{l}\mathrm{N}- \\
\text { Total }\end{array}$ & $\mathrm{PH}$ & $\mathrm{C} / \mathrm{N}$ & $\begin{array}{l}\text { Rata- } \\
\text { rata } \\
\text { KTK }\end{array}$ \\
\hline \multirow{4}{*}{$1-4$} & \multirow{4}{*}{ K } & 27,65 & 0,59 & 7,71 & 47 & \\
\hline & & 36,58 & 0,71 & 7,67 & 52 & \\
\hline & & 32,82 & 0,68 & 7,55 & 48 & \\
\hline & & 33,59 & 0,84 & 7,84 & 40 & 63,6 \\
\hline \multirow{4}{*}{$1-4$} & \multirow{4}{*}{ PKA1 } & 23,96 & 0,64 & 7,65 & 37 & \\
\hline & & 31,48 & 0,97 & 7,85 & 32 & \\
\hline & & 30,99 & 1,02 & 7,57 & 30 & \\
\hline & & 31,53 & 1,04 & 7,92 & 30 & 52,0 \\
\hline \multirow{4}{*}{$1-4$} & \multirow{4}{*}{ PKA2 } & 23,08 & 0,75 & 7,48 & 31 & \\
\hline & & 32,22 & 1,13 & 7.76 & 29 & \\
\hline & & 31,41 & 1,26 & 7,93 & 24 & \\
\hline & & 31,66 & 1,04 & 7,72 & 30 & 71,6 \\
\hline \multirow{4}{*}{$1-4$} & \multirow{4}{*}{ PKS1 } & 26,64 & 1,07 & 7,87 & 25 & \\
\hline & & 34,41 & 1,38 & 7,79 & 25 & \\
\hline & & 31,67 & 1,28 & 7,86 & 24 & \\
\hline & & 28,96 & 1,30 & 7,91 & 22 & 75,0 \\
\hline \multirow{4}{*}{$1-4$} & \multirow{4}{*}{ PKS2 } & 31,61 & 1,35 & 7,96 & 23 & \\
\hline & & 31,23 & 1,57 & 8,13 & 20 & \\
\hline & & 31,79 & 1,27 & 7,92 & 25 & \\
\hline & & 29,34 & 1,24 & 8,16 & 24 & 73,0 \\
\hline
\end{tabular}

Sumber: Lab Kimia, Biologi dan Kesuburan

Tanah Unsri, 2015
Tabel 3. Kandungan C- organik kompos

\begin{tabular}{ll}
\hline \multicolumn{1}{c}{ Konsentrasi } & \multicolumn{1}{c}{ C-Organik } \\
\hline PKA2 & $29,446 \mathrm{a}$ \\
PKA1 & $29,493 \mathrm{a}$ \\
PKS1 & $30,242 \mathrm{a}$ \\
PKS2 & $31,635 \mathrm{ab}$ \\
Kontrol & $32,663 \mathrm{~b}$ \\
\hline
\end{tabular}

Keterangan: angka pada kolom yang sama yang diikuti oleh huruf yang sama menunjukkan tidak berbeda nyata menurut uji Duncan pada taraf 5\%. Simbol PKA1 dan PKA2 merupakan kompos dengan pukan ayam $10 \%$ dan $20 \%$, sedangkan PKS1 dan PKS2 adalah kompos dengan pukan sapi $10 \%$ dan $20 \%$.

Tabel 4. Kandungan N- Total kompos

\begin{tabular}{ll}
\hline \multicolumn{1}{c}{ Konsentrasi } & \multicolumn{1}{c}{ N-Total } \\
\hline Kontrol & $0,704 \mathrm{~b}$ \\
PKA1 & $0,948 \mathrm{a}$ \\
PKA2 & $1,043 \mathrm{a}$ \\
PKS1 & $1,257 \mathrm{c}$ \\
PKS2 & $1,477 \mathrm{~d}$ \\
\hline
\end{tabular}

Keterangan: angka pada kolom yang sama yang diikuti oleh huruf yang sama menunjukkan tidak berbeda nyata menurut uji Duncan pada taraf 5\%. Simbol PKA1 dan PKA2 merupakan kompos dengan pukan ayam $10 \%$ dan $20 \%$, sedangkan PKS1 dan PKS2 adalah kompos dengan pukan sapi $10 \%$ dan $20 \%$.

Tabel 5. Kandungan pH kompos

\begin{tabular}{ll}
\hline \multicolumn{1}{c}{ Konsentrasi } & \multicolumn{1}{c}{$\mathrm{pH}$} \\
\hline Kontrol & $7,69 \mathrm{a}$ \\
PKA2 & $7,72 \mathrm{ab}$ \\
PKA1 & $7,75 \mathrm{ab}$ \\
PKS1 & $7,85 \mathrm{~b}$ \\
PKS2 & $8,04 \mathrm{c}$
\end{tabular}

Keterangan: angka pada kolom yang sama yang diikuti oleh huruf yang sama menunjukkan tidak berbeda nyata menurut uji Duncan pada taraf 5\%. Simbol PKA1 dan PKA2 merupakan kompos dengan pukan ayam $10 \%$ dan $20 \%$, sedangkan PKS1 dan PKS2 adalah kompos dengan pukan sapi $10 \%$ dan $20 \%$.

Analisis ragam pengaruh penambahan aktivator terhadap $\mathrm{pH}$ menunjukkan $\mathrm{pH}$ lebih tinggi pada pukan sapi $20 \%$ dan $\mathrm{pH}$ paling rendah pada kontrol, tetapi nilainya tidak jauh berbeda dengan pukan ayam $10 \%$, pukan ayam $20 \%$. 
Tabel 6. Komposisi C/N kompos

\begin{tabular}{ll}
\multicolumn{1}{c}{ Konsentrasi } & \multicolumn{1}{c}{$\mathrm{C} / \mathrm{N}$} \\
\hline PKS2 & 21,741 \\
PKS1 & 24,144 \\
PKA2 & 29,352 \\
PKA1 & 31,949 \\
Kontrol & 48,159 \\
\hline
\end{tabular}

Keterangan: angka pada kolom yang sama yang diikuti oleh huruf yang sama menunjukkan tidak berbeda nyata menurut uji Duncan pada taraf 5\%. Simbol PKA1 dan PKA2 merupakan kompos dengan pukan ayam $10 \%$ dan $20 \%$, sedangkan PKS1 dan PKS2 adalah kompos dengan pukan sapi $10 \%$ dan $20 \%$.

Analisis ragam pengaruh penambahan aktivator terhadap komposisi $\mathrm{C} / \mathrm{N}$ pada tabel 6. menunjukkan $\mathrm{C} / \mathrm{N}$ paling tinggi pada kontrol, $\mathrm{C} / \mathrm{N}$ yang paling rendah pada pukan sapi $20 \%$ tetapi nilainya tidak jauh berbeda dengan pukan sapi $10 \%$.

Tingkat kematangan kompos dapat dilihat dari rasio $\mathrm{C} / \mathrm{N}$ dan rasio C/P.pada tabel 6 . telah nampak perbedaan yang nyata antara limbah baglog jamur tiram dengan penambahan aktivator pukan sapi $20 \%$ (PKS2), nilai kandungan unsur hara pukan sapi relatif lebih baik dibandingkan dengan pukan sapi $10 \%$ ataupun pukan ayam $10 \%$ dan pukan ayam 20\%.baik rasio C/N 22 dan rasio $\mathrm{C} / \mathrm{P}$ berkisar $150 \mathrm{me} / 100 \mathrm{~g}$, meskipun bahan kompos tersebut belum memenuhi kriteria kematangan kompos.

\section{Suhu}

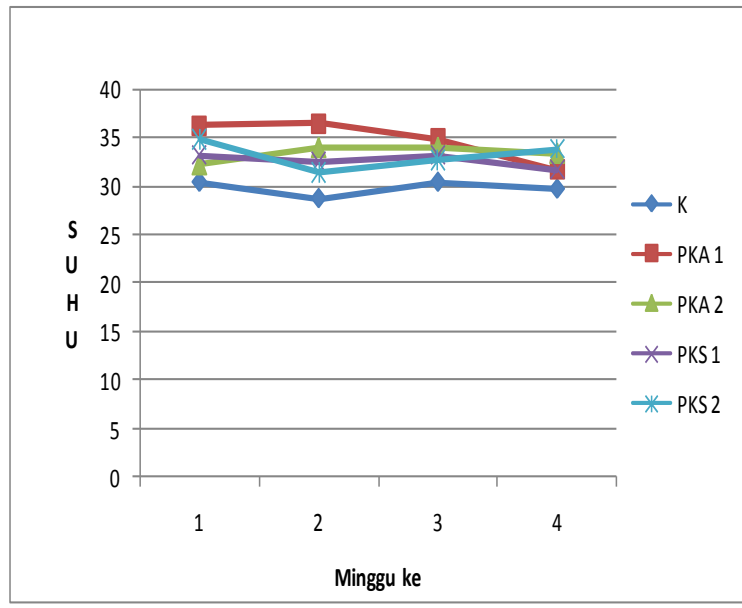

Gambar 2 Suhu kompos kedalaman $10 \mathrm{~cm}$

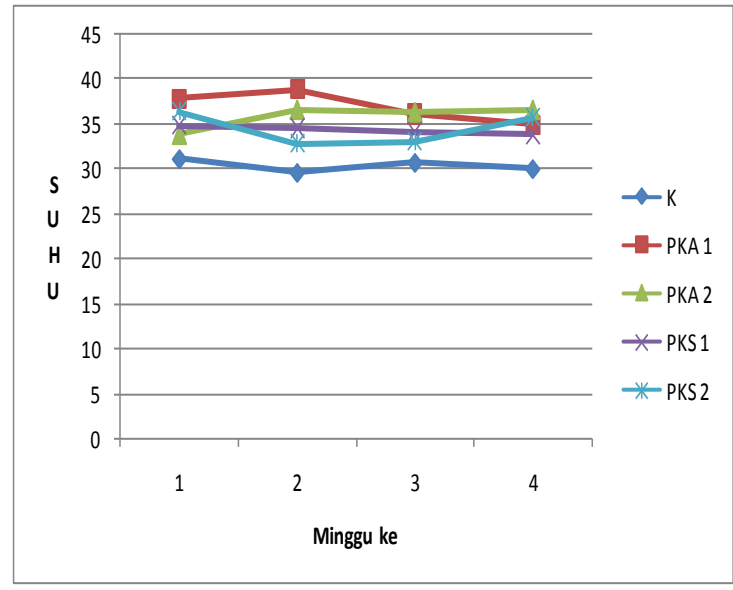

Gambar 3 Suhu kompos kedalaman $30 \mathrm{~cm}$

Suhu awal pengomposan berkisar antara 29 $-30^{\circ} \mathrm{C}$, suhu pengomposan pada tiap perlakuan mengalami peningkatan pada minggu pertama dan minggu kedua. Suhu optimal selama pengomposan berkisar 35 $45^{\circ} \mathrm{C}$.

Dalam perombakan bahan organik diiringi dengan pelepasan panas yang besar, mengakibatkan suhu pada tumpukan kompos meningkat. Kemudian aktivitas mikroba menurun diiringi dengan penurunan suhu tumpukan sampai proses pengomposan berakhir.

Pengaruh kompos limbah baglog jamur tiram (Pleurotusostreatus)sebagai media tumbuh sawi hijau (Brassica rapa var. parachinensis $\mathbf{L}$.)

\section{Karakteristik Tanah Media Tumbuh Sawi Hijau}

Hasil analisis tanah awal menunjukkan bahwa tanah latosol mempunyai kadar air $20 \%$,tekstur liat dengan kandungan pasir, debu, dan liat masing-masing sebesar $37,03 \%$, 24,76\% dan $38,21 \%$ Tanah tersebut tergolong tanah masam dengan $\mathrm{pH}$ 4,56.Kandungan C-organik tergolong rendah $(1,01 \%)$. Kandungan Nitrogen tanah tergolong rendah yaitu sebesar $0,10 \%$. Kandungan phospor $\left(\mathrm{P}_{2} \mathrm{O}_{5}\right)$ tanah tergolong sedang dengan kandungan sebesar 23,70 ppm. Kandungan basa-basa tanah berupa $\mathrm{K}$ sebesar $0,51 \mathrm{me} / 100 \mathrm{~g}$ (tinggi); $\mathrm{Na}$ sebesar $0,11 \mathrm{me} / 100 \mathrm{~g}($ rendah $) ; \quad \mathrm{Ca}$ sebesar $1,18 \mathrm{me} / 100 \mathrm{~g}$ (sangat rendah), dan $\mathrm{Mg}$ sebesar 0,45me/100g (rendah). Rasio $\mathrm{C} / \mathrm{N}$ 
tanah tergolong tinggi yaitu sebesar 10 . Kapasitas Tukar Kation (KTK) tanah tergolong rendah sebesar $15,23 \mathrm{me} / 100 \mathrm{~g}$, kejenuhan $\mathrm{Al}$ tergolong rendah yaitu sebesar $13,7 \%$, serta kejenuhan basa yang tergolong sangat rendah yaitu sebesar $14,77 \%$.

Tabel 6. Hasil analisis fisik dan kimia tanah latosol

\begin{tabular}{|c|c|c|c|}
\hline Parameter & Satuan & Hasil & Kriteria \\
\hline $\begin{array}{ll}\mathrm{pH} & \mathrm{H} 2 \mathrm{O} \\
(1: 1) & \end{array}$ & & 4,56 & Masam \\
\hline $\begin{array}{ll}\mathrm{pH} & \mathrm{KCl} \\
(1: 1) & \end{array}$ & & 4,40 & Masam \\
\hline C-Organik & $\%$ & 1,01 & Rendah \\
\hline N-Total & $\%$ & 0,10 & Rendah \\
\hline $\mathrm{P}_{2} \mathrm{O}_{5}$ & Ppm & 23,70 & Sedang \\
\hline K-dd & $\mathrm{me} / 100 \mathrm{~g}$ & 0,51 & Tinggi \\
\hline $\mathrm{Na}$ & $\mathrm{me} / 100 \mathrm{~g}$ & 0,11 & Rendah \\
\hline $\mathrm{Ca}$ & $\mathrm{me} / 100 \mathrm{~g}$ & 1,18 & $\begin{array}{l}\text { Sangat } \\
\text { rendah }\end{array}$ \\
\hline $\mathrm{Mg}$ & $\mathrm{me} / 100 \mathrm{~g}$ & 0,45 & Rendah \\
\hline KTK & $\mathrm{me} / 100 \mathrm{~g}$ & 15,23 & Rendah \\
\hline Kej Al & $\%$ & 13,7 & Rendah \\
\hline Kej basa & $\%$ & 14,77 & $\begin{array}{l}\text { Sangat } \\
\text { rendah }\end{array}$ \\
\hline
\end{tabular}

Sumber: Lab Kimia, Biologi dan Kesuburan Tanah Unsri, 2015

\section{Pertumbuhan Sawi Hijau}

Tiap polybag diisi dengan tanah $2 \mathrm{~kg}$,kadar air tanah lebih kurang 20\% maka untuk kontrol diisi dengan tanah $2,4 \mathrm{~kg}$. Untuk komposisi tiap perlakuan sebagai berikut:
$\mathrm{K} 1: 100$ tanah +0 kompos (v/v)
$\mathrm{K} 2: 80$ tanah +20 kompos (v/v)
$\mathrm{K} 3: 60$ tanah +40 kompos $(\mathrm{v} / \mathrm{v})$
K4 : 40 tanah +60 kompos $(\mathrm{v} / \mathrm{v})$
$\mathrm{K} 5: 20$ tanah +80 kompos (v/v)

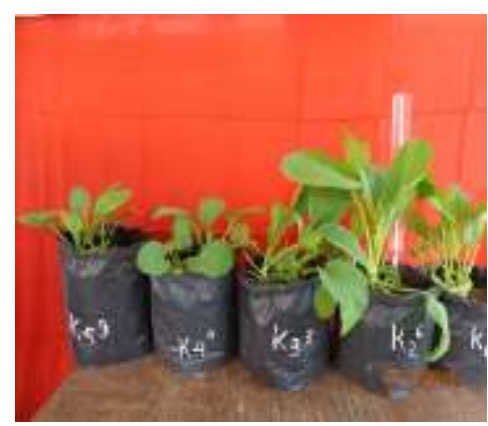

Gambar 4. Tanaman sawi hijau minggu ke 3

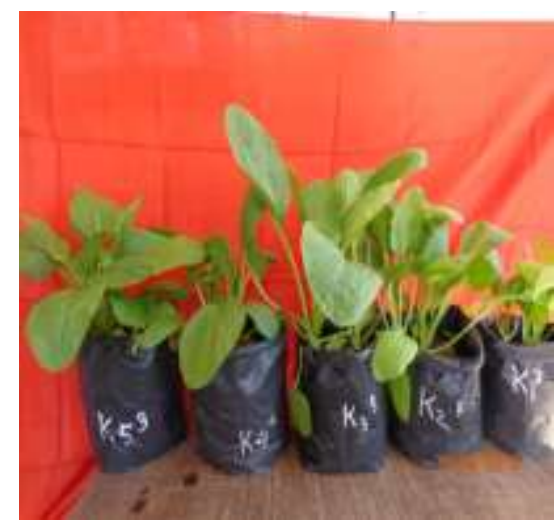

Gambar 5. Tanaman sawi hijau minggu ke 4

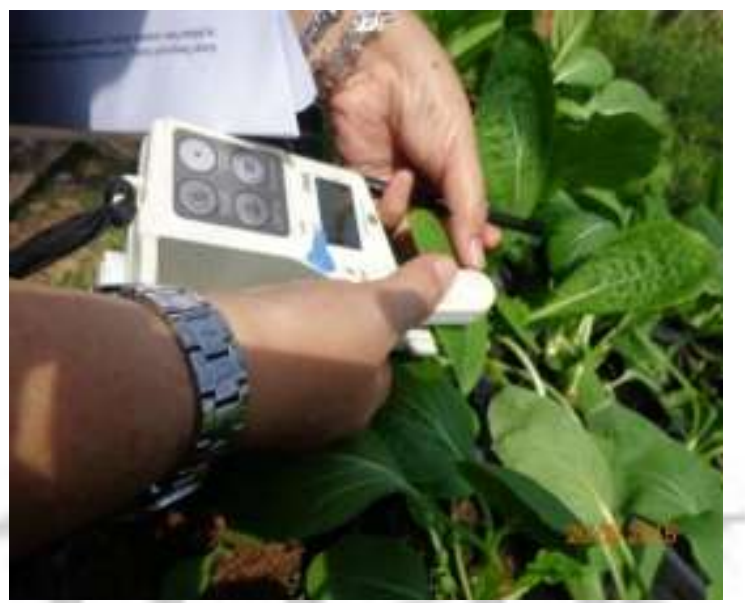

Gambar 6. Mengukur dengan khlorophyll meter

Jumlah daun mulai bertambah pada minggu ke empat berjumlah 4 lembar, luas daun $252,5 \mathrm{~cm}^{2}$, biomassa basah 42,22 gram, dan biomassa kering 2,46 gram. Jumlah klorofil 51,4 (daun atas/muda) dan 36,8 (daun bawah/tua)

\section{Ucapan Terima Kasih}

Ucapan terima kasih disampaikan kepada Program Studi Pengelolaan Lingkungan Jurusan Biologi Lingkungan Pasca Sarjana Universitas Sriwijaya. Universitas AndalasFakultas Teknik Jurusan Teknik Lingkungan, atas bantuannya dalam penerbitan jurnal penelitian ini. 
DAFTAR PUSTAKA

Aminah,S., G.B.Soedarsono, danY.Sastro. 2005.Teknologi Pengomposan. Jakarta: Balai Pengkajian Teknologi Pertanian Jakarta.

Arinong, A.R, H. Rukka, L Vibriana. 2008. Pertumbuhan dan Produksi Tanaman Sawi dengan Pemberian Bokashi. Jurnal Agrisistem, Desember 2008, Vol. 4 No. 2 ISSN 1858-4330. http://www.stppgowa.ac.id. Diakses 23-11-2014

Basuki. 1994. Pengomposan Tandan Kosong Kelapa Sawit dengan Pemberian Inokulan Fungi Selulotik, Nitrogen dan Fosfor.Tesis. Pasca srjana Jurusan Tanah.Institut Pertanian Bogor.

Djuarnani, Kristian, dan Setiawan. 2006. Cara Cepat Membuat Kompos. Agromedia Pustaka.

Gaspersz, V. 1995. Teknik Analisis Dalam Penelitian Percobaan. Penerbit Tarsito Bandung.

Gofar, N., Marsi., dan H. Widjajanti. 2013. Metode Pembuatan Bahan Pembawa Mikroba Pupuk Hayati Berbahan Baku Jerami Padi.Invensi Hak Paten.Kementerian Hukum dan Hak Asasi Manusia RI. Direktorat Jendral Hak Kekayaan Intelektual. No. 001/P/HKI/2000.

Gofar, N. dan Marsi. 2012. Dinamika Suhu, Biomassa, Unsur Hara, dan Populasi Bakteri selama Proses Pengomposan Jerami Padi untuk Penyediaan Pupuk Organik Berkualitas. Prosiding Seminar Nasional Menuju Pertanian yang Berdaulat, Fakultas Pertanian Universitas Bengkulu. 12 September 2012. ISBN: 9786029071078.

Hapsari, B. 2002.Sayuran Genjah Bergelimang Rupiah.Trubus 33(396) : 30-31.

Haryanto, E. T., Suhartini, dan E. Rahayu. 2001. Sawi dan Selada.Penebar Swadaya. Jakarta.

Hilman, Y. Dan N. Nurtika. 1992. Pengaruh Pupuk Kandang terhadap Pertumbuhan dan Produksi Tomat. Bulletin Penelitian Hortikultura Vol XXII(i); 96-101

Iskandar, S. 2003. Pengaruh Bokashi Produktivitas Tanaman Sayuran dalam Kegiatan Pertanian
Organik.Jurnal Agrotropika Vol VIII(2): 6-10.

Isroi. 2008. Cara Sederhana Menguji Kualitas Kompos. hhtp://isroi.com/2008/03/16/carasederhana-menguji-kualitas-kompos/ Diakses 13 November 2014.

Kardin, D. 2005. Teknologi Kompos. www.diperta.jabarprov.go.id. Diakses 13 November 2014

Lingga Pinus dan Marsono. 2013. Petunjuk Penggunaan Pupuk. Penerbit Penebar Swadaya, Jakarta.

Manurung, H, dan E.D Resmi. 2010. Uji Efektivitas Bioaktivator Orgadec dan EM-4 Terhadap Pembentukan Kompos Dan Penurunan Kadar C/N Limbah Daun Ketapang (Terminalia catappa Linn). Jurusan Biologi FMIPA. Universitas Mulawarman. Bioprospek, volume 7, November II, September 2010. ISSN: 1829-7226. http://fmipa.unmul.ac.id. Diakses 1311-2014.

Margiyanto, E. 2008. Budidaya Tanaman Sawi. ttp://zuldesains.wordpress.com. Diakses 18-09-2014

Meinanda, I. 2013. Panen Cepat Budidaya Jamur. Penerbit Padi.

Melati, M. dan Andriyani, W. 2005. Pengaruh Pupuk Kandang Ayam dan Pupuk Hijau Calopogonium mucunoides Terhadap Pertumbuhan dan Produksi Kedelai Panen Muda yang Dibudidayakan Secara Organik Bul. Agron. (33) (2) 8 - 15 (2005). http://www.journal.ipb.ac.id. Diakses 16-11-2014

Muslihah.S., Sulfahri, R.S Utami., E Sunarto., dan I.D.A.A Warmadewanthi. 2011. Pengaruh Jenis Bahan Perekat Dan Metode Pengeringan Terhadap Kualitas Briket Limbah Baglog Jamur Tiram Putih (Pleuratus ostreatus). Berkala Hayati $17: 47-51$.

Musnamar. E. I. 2003. Pupuk Organik: Cair dan Padat, Pembuatan, Aplikasi. Penebar Swadaya. Jakarta

Novizan.2007. Petunjuk Pemupukan yang Efektif. Jakarta: Agromedia Pustaka.

Nugroho, A.W.2006. karakteristik Tanah Pada Sebaran Ulin di Sumatera Dalam Mendukung Konservasi (Prosiding) 
Palembang: Balai Litbang Hutan Tanaman Palembang.

Pujisiswanto.H. danD. Pangaribuan. 2008. Pengaruh Dosis Kompos Pupuk Kandang Sapi Terhadap Pertumbuhan Dan Produksi Buah Tomat. Prosiding Seminar Nasional Sains dan Teknologi-II 2008. Universitas Lampung, 17-18 November 2008. ISBN: 978-979-1165-74-7.

Diakses 13 November 2014

Purnawanto.A.M. dan O.D Hajoeningtijas. 2005. Kajian Penggunaan Limbah Media Tanam Jamur Tiram Sebagai Pupuk Organik Alternatif Pada Budidaya Kacang Tanah (Arachis hypogaea). Fakultas Pertanian Universitas Muhammadiyah Purwokerto.jurnal.ump.ac.id/index.ph $\mathrm{p}$

/agritech/article/download/385/363.Di akses 20 Agustus 2014.

Purwanto.2005.Pengaruh PupukMajemukNPKdanbahan pemantap tanahterhadap hasildankualitastomat varietas intan.JournalPenelitianUNIB,Maret200 5.XI (1):56-60.

Rakhmiati, Yatmin, Fahrurrozi. 2003. Respon tanaman sawi terhadap proporsi dan takaran pemberian $N$. Jurnal Wacana Pertanian Vol. III. Hal 119-121. Bandar Lampung.

Santoso, B., U.S Budi., dan E Nurnasari. 2012.PengaruhJarakTanamDanDosisP upukNpkMajemukTerhadap

Pertumbuhan,ProduksiBunga,Dan AnalisisUsahaTaniRoselaMerah. Balai Penelitian Tanaman Tembakau dan Serat Malang.JurnalLittri 18(1),Maret2012.Hlm.17-23

ISSN0853-8212.Diakses

Desember 2014

Sinukaban, N. 2007. Konservasi Tanah dan Air: kunci Pembangunan dan Berkelanjutan. Jakarta: Direktorat Jenderal RI.PS Departemen Kehutanan.

Sukristiyonubowo.2007. NutrientBalancesin

Terraced PaddyFieldsunder

TraditionalIrrigationinIndonesia.Facult yofBioScienceEngineering GhentUniversity.Ghent, Belgium184p.(Unpublished).
Sulaeman, D.2011. Efek Kompos Limbah Baglog Jamur Tiram Putih (Pleurotusastreatus Jacquin) Terhadap Sifat Fisik Tanah Serta Pertumbuhan Bibit Markisa Kuning (Passiflora edulis var. Flavicarpa Degner). Fakultas Pertanian,.IPB.http://repository.ipb.ac. id/handle/12345678953343. Diakses 16 September 2014.

Sunarjono, H. 2004. Bertanam 30 Jenis Sayur. Penebar Swadaya, Jakarta.

Suryani, A. 2007. Perbaikan Tanah Media Tanam Jeruk Dengan Berbagai Bahan Organik Dalam Bentuk Kompos (Tesis). Bogor: Sekolah Pascasarjana Institut Pertanian Bogor.

Sutanto, R. 2002. Penerapan Pertanian Organik. Penerbit Kanisus, Yogyakarta.

Sutedjo, M. M. 2010. Pupuk dan Cara Pemupukan. Penerbit Rineka Cipta, Jakarta.

Suwahyono, U. 2014. Cara Cepat Buat Kompos dari Limbah. Penebar Swadaya, Jakarta.

Yenie, E. 2008.Kelembaban Bahan dan Suhu Kompos Sebagai Parameter yang Mempengaruhi Proses Pengomposan Pada Unit Pengomposan Rumbai. Jurnal Sains dan Teknologi Vol. 7 (2): 58-61

Yuliarti, N. 2009.1001 Cara Menghasilkan Pupuk Organik. ANDI, Yogyakarta.

Yuliastuti.ES.E dan A Susilo. 2003. Studi Kandungan Nutrisi Limbah Media Tanam Jamur Tiram Putih (Pleuratus ostreatus) Untuk Pakan Ternak Ruminansia.

Yuwono, D. 2007. Kompos: Dengan Cara Aerob Maupun Anaerob untuk Menghasilkan Kompos berkualitas. Jakarta: Penebar Swadaya.

Winarso, S. 2005. Kesuburan Tanah. Dasar Kesehatan dan Kualitas Tanah.Penerbit Gava Media, Yogyakarta.

Zhyahrial, F. F., Rahayu, Y. S., dan Yuliani. 2014. Bioremediasi dengan Teknik Biostimulasi Tanah Tercemar Minyak Bumi dengan Menggunakan Kompos Kombinasi Limbah Media Jamur Tiram Putih (Pleurotus ostreatus) dan Azolla. Lentera Bio 3 ( 3) : hal 141hal 146 . 